\begin{tabular}{rr} 
çaḡdaş & Yaratıcı Drama Dergisi 2018, 13(1), 53-68 \\
drama & www.yader.org \\
\hline
\end{tabular}

\title{
T.C. İnkılâp Tarihi ve Atatürkçülük Dersinin Yaratıcı Drama Yöntemi ile İşlenmesine İlişkin Öğrenci Görüşleri
}

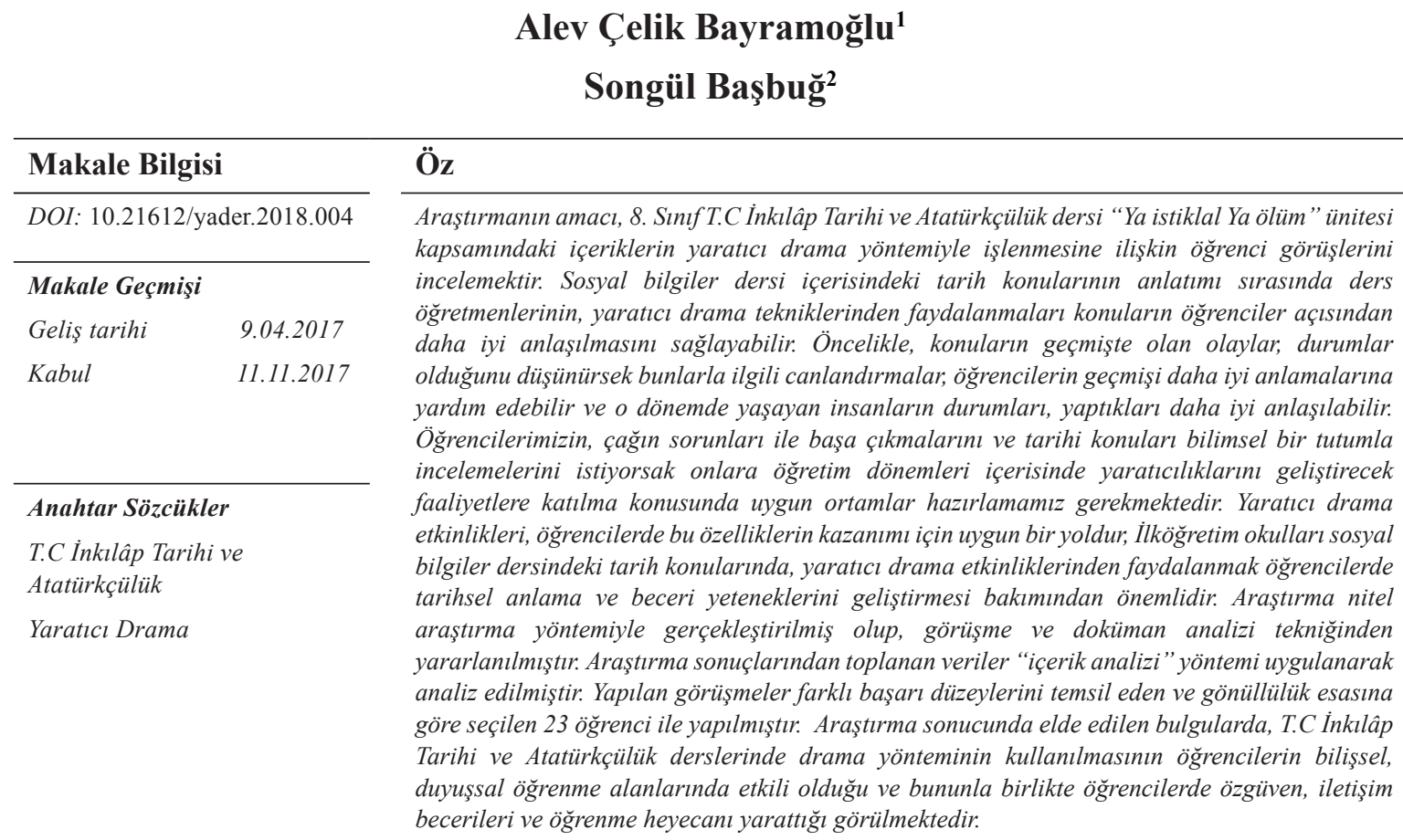

\section{Student Views on The Republic of Turkey Revolution History and Kemalism with Creative Drama Method}

\begin{tabular}{ll}
\hline Article Info \\
\hline DOI: $10.21612 /$ yader.2018.004 \\
\hline Article History & \\
Received & 9.04 .2017 \\
Accepted & 11.11 .2017
\end{tabular}

Keywords
Creative Drama
The Republic of Turkey
Revolution History and
Kemalism

\section{Abstract}

The purpose of there search is to teach the content of the Unit 8, Liberty or Death, in the lesson of The Republic of Turkey Revolution History and Kemalism using creative drama method and observing its effetcs on students. Using creative drama techniques while teaching history subjects in social sciences lesson may help students understand the subjects better. In the first place, if we consider the subjects are events and occasions which took place in the past, the improvisationsre lated to the see events may help students interpret the past and the people better. If we want to teach our students how to deal with the issues of this era, how to study history subjects with a scientific attitude and that history is a living phenomenon, we need to prepare suitable environment for them to participate in the activities which will prove their creatvity. Creative drama tasks are favorable way for the acquisition of these characteristics by students. It is important to benefit creative drama techniques while teaching history subjects in social sciences lesson at primary schools in order to improve students' historical comprehension. In this study, interview and document analys is method, which is one of the subjective search methods, has been used. The data collected from there search results were analised by applying the "content analysis". The interviews have been made with 23 volunteer students representing different levels of success. As a result of the study, it has been observed that the use of drama techniques in history lesson shave positive effects on students' cognitive and affective abilities.

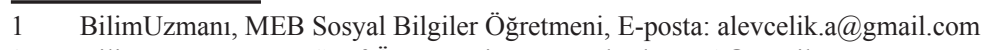

2 Bilim Uzmanı MEB Sını Öğretmeni, E-posta: basbugs71@gmail.com 


\section{Giriş}

Tarih; geçmişi, bugünü, yarını barındıran, tarihsel gelişmeleri neden-sonuç ilişkisi içinde objektif değerlendirmeyi amaçlayan bir bilimdir. 'İnsanın, insanlığın ve kültürlerin belleği' olarak da tanımlanan tarih disiplini, insanın ya da insanlığın olumlu ya da olumsuz anlamda ortaya koyduklarının anlamlandırıldığı ve eleştirel bir perspektiften değerlendirmelerinin yapıldığı bir disiplin alanıdır (Kabapınar, 2014). Carr'a(1996) göre, insanlık için bugünün anlaş1labilmesi geçmişin anlaşılmasına bağlıdır. Geleceğe daha sağlam adım atabilmek için bu şarttır. Bu bakımdan geleceği oluşturacak nesillere tarih öğretmek oldukça önemli bir iştir.

Türkiye' de tarih eğitimine bakıldığında henüz istenilen düzeye ulaşamadığı düşünülmektedir. Tarih Vakfi tarafindan hazırlanan Tarih eğitimi strateji raporunda belirtildiği gibi Türkiye'de eğitim malzemelerinin, teknolojideki gelişmeler dikkate alınarak çeşitlendirilmesine, öğretmen-ders notukitap üzerine kurulu ders işleme yöntemlerinin, geziler, sınıf dışı çalışmalar, oyunlar rol paylaşımları eleştirel okumalar, tartışmalar, video ve CD’lerle zenginleştirilmesine geçilmesi zorunludur (Silier, 2003). Demircioğlu'na (2010) göre, tarih derslerinde olgu, kavram ve genellemelerin aynen ezberletilmesini beklemek ve tarih öğretiminde geleneksel yöntemleri kullanılmak, öğrencilerin derse bakış açısını olumsuz yönde etkilemektedir.

Özbaran'ın da (1992) belirttiği gibi Atatürk İlkeleri ve İnkılâp Tarihi dersi ile çağdaş tarih öğretiminde geçmiş ile günümüz arasında kurulmak istenen diyalog gerçekleştirilememiş; tarih diye okutulanlar, anlatılanlar ve dikte ettirilenler geçici görevlerini yerine getirdikten sonra unutulup gitmiştir. Sonuç itibariyle, ezbercilikten, sınırlandırmalardan, kesin tavırlardan olumlu sonuç elbette beklenemez. Tarih içeriğinin gerek sadece bilişsel alana dönük olması, gerekse bugün uygulamada görülen bazı eksiklik ve aksaklıklar yüzünden amacı gerçekleştirmekten çok uzak olduğu görülmektedir. Her şeyden önce düz anlatım ya da soru cevap gibi birkaç klasik yöntemin dışına pek çıkılmadan, ders kitabı dışında ders araç ve gereçlerinin pek kullanılmadığı, oldukça sıkıcı, hatta kaygı ve korku verici bir ortamda geçen derslerin yukarıda sayılan amaçlara sahip bireyleri yetiştirmek hedefinden uzak olduğu açıktır. Ezbere dayalı olan öğretim yöntemi, konular sınav sistemine dönük olarak işlendiği için, adeta içi boş ezberlenmiş isim, kronoloji ve madde şekline dönüşmektedir (Dönmez, 2005).

Tarih, dolayısıyla İnkılâp Tarihi geçmişin o günkü şartları göz önünde bulundurularak bugünkü bakış açımızla yeniden inşasıdır. Bu anlamda soyuttur. Özellikle soyut işlemler dönemine geçmemiş öğrencilerin bakış açısından kendi hayatlarıyla yakından ilgili değildir. Öğretimin temel prensipleri arasında basitten-karmaşığa, yakından-uzağa, somuttan soyuta doğru bir ilerlemenin olması gerekliliği vardır (Demircioğlu, 2009). Black'a göre (2003), bir derste öğrencilerin kavrama oranı okuma yaparlarsa \%10, görsel-işitsel yöntemler kullanılırsa \%20, gösteri ile ders anlatılırsa \%30, grup tartışması olursa \%50, uygulamalı öğrenirlerse \% 75 , başkalarına öğreterek öğrenirse \%90 olur. Kabapınar'a (2014) göre, sosyal bilgiler gibi derslerin varoluş gerekçelerinin en önemlilerinden biri hayatın kendisini öğrenciye tanıtmak, yaşam içinde karşılaşacağı olay ve durumlara ilişkin farkındalık kazandırmaktır. Bu anlamda «yaparak, yaşayarak öğrenme» öğrenilenlerin kalıcılı̆̆ını arttırma ve dersin amaçlarının yerine getirilmesi noktasında önem kazanmaktadır. Bu nedenle çocukların dokunmaları, görmeleri ve duymaları gerekmektedir. Böyle bir eğitim süreci hem eğlenceli hem de faydalıdır. 
Öğrenciyi aktif kılma çabalarından biri olarak; yaratıcılık, eğitimde amaçların değişmesi ile birlikte dikkat çeken konulardan biridir. Okullar bir yandan yaratıcılığı öldürmekle suçlanırken, diğer yandan okulun yaratıcılığı geliştirme işlevi önem kazanmış ve bu yöndeki çalışmalarda artış görülmüştür (Açıkgöz, 1998). Yaratıcılık tanımlarından yola çıkılarak “yeni bir şey” ortaya koyma düşüncesi genellikle sayısal derslere atfedilmiş, sözel olarak tanımlanan tarih, coğrafya, edebiyat gibi dersler ise yalnızca ezberlenebilecek, yeni bir şey üretilmeyen sıkıcı dersler olarak görülmüştür. Bu dersler içinde özellikle tarih, öğrenciler tarafindan ezberlenemeden asla öğrenilemeyecek bir ders olarak tanımlanmıştır (Safran, 2006). Bu sebepten dolayı Safran (2009), tarih öğretimini, eğitim sistemimizdeki en sorunlu alanlardan biri olarak tarif eder.

Sosyal bilimlerin önemli disiplinleri arasında yer alan tarihin öğretiminde karşılaşılan önemli problemlerden birisi, öğretimi yapılan konuların öğrencilerin yaşadıkları zaman diliminden çok önce cereyan etmiş olmasıdır. Bazı öğrenciler, kendi yaşam ve deneyimlerinden uzak tarihi olaylara ilgi göstermemekte ve bu öğrencilerde, tarih öğretimiyle istenilen davranış değişiklikleri meydana getirilmektedir. $\mathrm{Bu}$ durumda yapılması gereken, birinci ve ikinci elden tarihi bilgi barındıran materyal ve metinlerin 1şığı altında, öğrencileri aktif hale getirecek etkinlikler aracılığıyla tarihi bizzat yaşatmaktadır. Tarih derslerinde geçmişi bugüne getirip öğrencileri aktif ve üretken kılabilecek öğretim etkinliklerinin başında drama gelmektedir.

Drama; bir grupla ve grup üyelerinin yaşantılarından yola çıkarak, bir amacın, düşüncenin, doğaçlama, rol oynama (rol alma) vd. tekniklerden yararlanarak canlandırılmasıdır. Bu canlandırma süreçleri deneyimli bir lider/eğitmen eşliğinde yürütülürken kendiliğindenliğe (spontaniteye), şimdi ve burada ilkesine, - mış gibi yapmaya dayalıdır ve yaratıcı drama, oyunun genel özelliklerinden doğrudan yararlanır (Adıgüzel, 2017, s.41). Yaratıcı dramanın temelinde oyunlar yoluyla öğrenme vardır. Oyunlar çocuğun hem doğal hem de sosyal çevresini oluşturmaktadır. Oyunlarda çocuğun fizyolojik ve psikolojik birçok özelliği olumlu yönde gelişirken öğrenmenin düzeyi de yükselir.

Sosyal bilgiler dersi içerisindeki tarih konularının anlatımı sırasında ders öğretmenlerinin, yaratıcı drama tekniklerinden faydalanmaları konuların öğrenciler açısından daha iyi anlaşılmasını sağlayabilir. Öncelikle, konuların geçmişte olan olaylar, durumlar olduğunu düşünürsek bunlarla ilgili canlandırmalar, öğrencilerin geçmişi daha iyi anlamalarına yardım edebilir ve o dönemde yaşayan insanların durumları, yaptıkları daha iyi anlaşılabilir (Üstündağ, 2002). Yaratıcı drama etkinlikleri planlanırken grubun gereksinimleri ve ön yaşantıları dikkate alınır. Grubu düşünmeye, yorumlamaya, olaylar arasında bağ kurmaya, iyi bir gözlem yapmaya özendirecek biçimde yapılandırılır (Başbuğ ve Aykaç, 2012, s.191). Bu etkinliklerde öğrencilerin, belli bir olayı veya durumu yeniden canlandırma firsatı sağlayarak, tarihsel olayları ve sorunları anlayıp yorumlaması belli bir zaman döneminde yaşamış, sade bir vatandaşın günlük hayatını anlaması amaçlamaktadır (Stradling, 2003 ).

Demircioğlu'na göre (2010); tarih dersleri bünyesinde öğrencilerin yaparak ve yaşayarak öğrenebilecekleri etkinliklerden birisi dramadır. Hedeflenen davranış değişikliklerini meydana getirmek amacıyla olay, olgu ve durumların öğrenciler tarafından oyunlaştırılmasıyla edinilen yaşantılar olarak karşımıza çıkan drama, pek çok nitelik ve becerinin öğrencilere kazandırılmasında yardım eder. Şengül'e göre (2011); tarihe drama yoluyla yaklaşan öğrenci; tarihsel olay ve olguları içselleştirir, tarihsel empati kurabilir, olaylara çok perspektifli bir bakış açısından bakabilir ve olayları hayal ederek zihinde daha anlamlı hale getirebilir. 
Tarih konularında yaratıcı drama etkinliklerinin kuIlanılması öğrencilere:

1. Ortak bir amaç için diğer öğrencilerle işbirliği yaparak çalışmayı ve aktif bir katılım içerisine girmeyi

2. Farklı fikirlere ve görüşlere hoşgörüyle yaklaşma gibi bir deneyi yaşamayı

3. İletişim becerilerini kullanmayı ve daha da geliştirmeyi

4. Sorgulama ve sorun çözme becerilerini geliştirmeyi

5. Ders kitaplarından, diğer birincil ve ikincil kaynaklardan daha önce edindikleri bilgileri, bir olayı ya da durumu yaratıcı bir yaklaşımla yeniden kurgulamada kullanabileceklerini göstermeyi sağlar (Stradling, 2003).

Tarih öğretiminde kullanılacak öğretim yöntem ve teknikleri arasında; yaparak yaşayarak öğrenmeyi sağlayacak, öğrenmede öğrenciyi sürecin içinde tutan, konudan ve ortamdan uzaklaştırmayan, keyifli öğrenme süreçleri yaratan öğretim yöntem ve teknikleri önemlidir. Eğitim hedeflerinin gerçekleştirilmesinde ve eğitim durumlarının düzenlenmesinde yöntemin önemli bir yeri vardır. Öğretme-öğrenme süreçlerinin etkili olabilmesi için sürece uygun yöntem ve tekniklerin seçilmesi ve planlaması, çocuğu sürece bir bütün olarak katması ve onu süreçte etkin kılması açısından büyük bir öneme sahiptir (Başbuğ, 2008).

Tarih derslerinde yürütülecek drama etkinlikleriyle, önemli davranış değişiklikleri meydana getirilebilir. Bu etkinlik aracılığıyla geçmişteki olay, insan ve durumlar temsili olarak bugüne taşınabilir ve öğrencilere, geleneksel öğretim etkinlikleriyle kazanamayacakları pek çok deneyim, beceri ve tarihsel nitelik kazandırılabilir (Barth ve Demirtaş, 1997).

Hedeflenen davranış değişikliklerini meydana getirmek amacıyla olay, olgu ve durumların öğrenciler tarafından oyunlaştırılmasıyla edinilen yaşantılar olarak karşımıza çıkan drama, pek çok nitelik ve becerinin öğrencilere kazandırılmasına yardım eder. Dramaya dayalı tarih derslerinde, öğrenciler belirli bir sorumluluk çerçevesinde, geçmişi bugüne getirmeye çalışırlar. Beraber paylaşabilme, toplum önünde konuşma, canlandırdıkları tarihsel figürlerle empati gibi pek çok etkinliği yapan öğrenciler, anlatıma dayalı tarih derslerinde kazandırılması mümkün olmayan pek çok nitelik ve beceriyi yaparak ve yaşayarak kazanabilirler. Bununla birlikte tarih öğretiminde drama etkinliklerinden istenilen verimin alınabilmesi için, öğretmenlerin bu etkinlikleri nasıl yürüteceklerini çok iyi bilmeleri gerekmektedir (Demircioğlu, 2009).

Öğrencilerimizin, çağın sorunları ile başa çıkmalarını, tarihi konuları bilimsel bir tutumla incelemelerini ve tarihin yaşayan bir olgu olduğu gerçeğini öğretmek istiyorsak onlara öğretim dönemleri içerisinde yaratıcılıklarını geliştirecek faaliyetlere katılma konusunda uygun ortamlar hazırlamamız gerekmektedir. Yaratıcı drama etkinlikleri, öğrencilerde bu özelliklerin kazanımı için uygun bir yoldur, sosyal bilgiler dersindeki tarih konularında, yaratıcı drama etkinliklerinden faydalanmak öğrencilerde tarihsel anlama ve beceri yeteneklerini geliştirmesi bakımından önemlidir. Tüm bu verilerden yola çıkılarak T.C. İnkılâp tarihi ve Atatürkçülük dersinin de soyut ve tekdüze bir anlatım yerine öğrencilerde yaşantı oluşturarak somut hale getirilmesi günümüzde önemli bir gerekliliktir. Bu nedenle yaratıcı drama yöntemi ile işlenen derslere ilişkin öğrenci görüşlerinin ortaya konması araştırmaya değer bir konu olarak düşünülmüştür. 


\section{Araştırmanın Amacı}

Bu araştırmada, 8. Sınıf T.C. İnkılâp Tarihi ve Atatürkçülük dersi "Ya istiklal Ya ölüm" ünitesi kapsamındaki içeriklerin yaratıcı drama yöntemiyle işlenmesine ilişkin öğrenci görüşlerini incelemek amaçlanmıştır. Bu temel amaç doğrultusunda aşağıdaki sorulara yanıt aranmıştır:

1. Öğrencilerin yaratıcı drama etkinliklerine yönelik görüşleri nelerdir?

2. Öğrencilerin ders işlenişi ile ilgili düşünceleri ve beklentileri nelerdir?

3. Öğrencilerinin atölye sürecine ilişkin görüşleri nelerdir?

\section{Araştırmanın Yöntemi}

Araştırmada nitel araştırmada kullanılan, yarı yapılandırılmış görüşme tekniği ve doküman analizi uygulanmıştır. Araştırmada tipik durum örneklemi kullanılarak seçilen 8. sınıf öğrencileri ile yarı yapılandırılmış görüşme soruları ile görüşmeler yapılmıştır. Görüşme formunun pilot uygulaması yapıldıktan sonra, tarih ve sosyal bilgiler öğretimi alanında görev yapan öğretim elemanlarından uzman görüşü alınmış ve soruların görüşmeye uygunluğu tartış1lmıştır. Son biçimini alan görüşme formu kullanılarak yapılan görüşmeler için önceden izin ve randevu alınmıştır. Görüşmeler yaklaşık 15-20 dakika arasında sürmüştür. Verilerin çözümlenmesinde öğrencilerin ses kayıtları bir metin haline getirilmiş; Microsoft Word ortamında toplamda 83 sayfalık bir ham veri dokümanı oluşturulmuştur. Buna ek olarak tüm süreç boyunca öğrenciler günlük tutmuşlardır. Görüşme yapılan öğrencilere ait günlüklerde yer alan bilgilerde öğrencilerin görüşlerine dair bütüncül bir bakış açısı ortaya çıkarılmaya çalışılmıştır. Araştırma sonuçlarından toplanan veriler "içerik analizi” yöntemi uygulanarak analiz edilmiştir. İçerik analizi dökümanların, görüşme dökümlerinin ya da kayıtların karakterize edilmesi ve karşılaştırılması için kullanılan bir tekniktir. Amacı, katılımcıların görüşlerinin içeriklerinin sistematik olarak kodlanmasıdır. Böylece araştırmacı toplanan verilere aşina olmakta ve ayrıca verilerin daha ileri analizler için kullanılması kolaylaşmaktadır (Altunışık ve diğerleri, 2005). Yapılan görüşmeler tipik durum örneklemi kullanılarak seçilen 23 öğrenci ile yapılmıştır. Dış geçerliliği sağlamak için araştırma süreci ayrıntılı bir şekilde anlatılmıştır. Mevcut çalışmada öğrenci yanıtlarına ait doğrudan alıntılar tırnak içerisinde ve hiçbir değişiklik yapılmadan sunulmuştur. Kodlar verilerek öğrencilerin görüşlerine yer verilmiştir. Örneğin Ö1 birinci öğrenciyi ifade etmektedir. Araştırmanın güvenirliği iki kodlayıcı ile elde edilmiştir. Görüş birliği/ (görüş birliği+görüş ayrılığı) yöntemi ile güvenirlik katsayımız 18/(18+5)=0,78 yani \%78 olarak bulunmuştur. Güvenirlik formülü Miles ve Huberman'a aittir. Kısaca elde edilen bulgular, sistematik ve açık bir şekilde betimlenmiş, betimlemeler düzenlenmiş ve yorumlanmıştır.

Araştırmada üç tema belirlenmiş olup bu temalar ve temalara ilişsin sorular sırasıyla aşağıdaki gibidir;

1. 8. Sınıf öğrencilerinin Yaratıcı Drama etkinliklerine yönelik görüşleri nelerdir?

- Drama konusunda ne düşünüyorsun?

- Daha önce hiç drama dersi aldın mı?

- Sence drama yöntemi ile ders işlenebilir mi?

- Proje kapsamında yapılan atölyelerin size hangi açılardan katkı sağladığını düşünüyorsunuz?

- Drama atölyeleri ile dersi daha iyi anladığınızı düşünüyor musunuz? 
- Sence Dramanın olumlu ve olumsuz özellikleri nelerdir?

- Müzede drama uygulaması ile ilgili düşünceleriniz nelerdir?

\section{8. Sınıf öğrencilerinin ders işlenişi ile ilgili düşünceleri ve beklentileri nelerdir?}

- İnk1lâp Tarihi dersini seviyor musunuz?

- Dersi nasıl işliyorsunuz?

- Derste farklı etkinliklerin uygulanmasını ister misiniz?

- Sosyal bilgiler öğretmeni olsan dersi nasıl işlerdin?

\section{8. Sınıf öğrencilerinin atölye sürecine dair görüşleri nelerdir?}

- $\quad$-Atölye sürecine ilişkin hissettiklerin nelerdir?

- $\quad$-Atölye sürecinde öğrendiklerin nelerdir?

\section{Bulgular}

\section{Sınıf öğrencilerinin Yaratıcı Drama etkinliklerine yönelik görüşlerine ilişkin bulgular}

Tema 1: 8. Sını öğrencilerinin Yaratıcı Drama etkinliklerine yönelik görüşleri

Tablo 1. Dramanın tanımı

\begin{tabular}{|c|c|c|}
\hline Tema & Kodlar & f \\
\hline $\begin{array}{c}\text { Dramanın } \\
\text { tanımı }\end{array}$ & 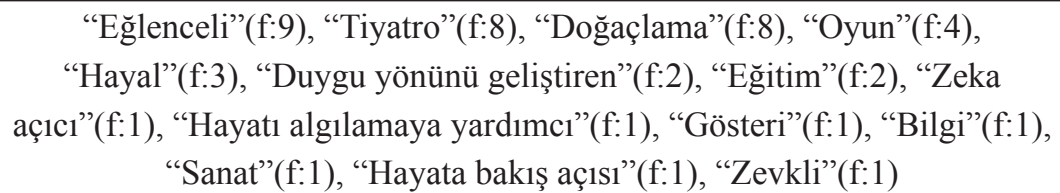 & 43 \\
\hline
\end{tabular}

Tablo 1'de görüldüğü gibi, öğrencilere birinci tema doğrultusunda dramanın tanımı sorulmuştur. Öğrencilerin verdikleri cevaplardan hareketle en çok, "Eğlenceli(f:9)", "Tiyatro(f:8)" ve "Doğaçlama(f:8)" kodlarının ön plana çıktığı görülmektedir. Bundan sonra sırasıylaOyun(f:4), Hayal(f:3), Duygu yönünü geliştiren(f:2), Eğitim(f:2), Zeka açıcı(f:1), Hayatı algılamaya yardımcı(f:1), Gösteri(f:1), Bilgi(f:1), Sanat(f:1), Hayata bakış açısı(f:1), Zevkli(f:1) kodları yer almaktadir.

Aşağıda öğrencilerin yaptıkları açıklamalardan örnekler verilmiştir.

Drama doğaçlama ile bi de eğlenceli bir tiyatroya benzer.(Ö2)

Drama insanların herhangi bir konu hakkında bir araya gelerek doğaçlama yapmasıdır. (Ö12) 
Tablo 2. Daha önce drama dersi alma durumu

\begin{tabular}{|c|c|c|}
\hline Tema & Kodlar & f \\
\hline $\begin{array}{c}\text { Daha önce } \\
\text { drama dersi alma } \\
\text { durumu }\end{array}$ & "Hayır”(f:15) & 23 \\
\hline
\end{tabular}

Tablo 2'de görüldüğü gibi, öğrencilere birinci tema doğrultusunda daha önce drama dersi alıp almadıkları sorulmuştur. Öğrencilerin verdikleri cevaplardan hareketle en çok, "Hayır(f:15)" kodunun ön plana çıktığı görülmektedir. Bundan sonra ise "Evet(f:8)" kodu yer almaktadır.

Tablo 3. Drama yöntemi ile ders işleme konusundaki düşünceler

\begin{tabular}{|c|c|c|}
\hline Tema & Kodlar & f \\
\hline $\begin{array}{l}\text { Drama } \\
\text { yöntemi ile } \\
\text { ders işleme }\end{array}$ & 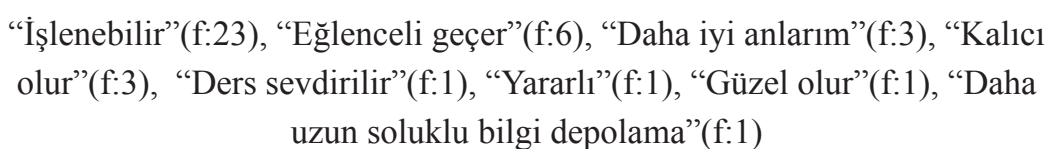 & 38 \\
\hline
\end{tabular}

Tablo 3'de görüldüğg̈ gibi, öğrencilere birinci tema doğrultusunda Drama yöntemi ile ders işlenmesi konusundaki düşünceleri sorulmuştur. Öğrencilerin verdikleri cevaplardan hareketle en çok, "İşlenebilir(f:23)" ve "Eğlenceli geçer(f:6)" kodlarının ön plana çıktığı görülmektedir. Bundan sonra sirasıyla“Daha iyi anlarım(f:3)", "Kalıcı olur(f:3)", "Ders sevdirilir(f:1)", "Yararl1(f:1)", "Güzel olur(f:1)"kodları yer almaktadır.

Aşağıda öğrencilerin yaptıkları açıklamalardan örnekler verilmiştir.

İslenir, derslerimi daha iyi anlamama yardımcı oldu.(Ö20)

Görsel hafizanin günlük hayatta daha fazla göz önünde durduğunu düşündüğümüzde daha kalıc ya da daha uzun soluklu bilgiler depo edebiliriz, bu sayede yani kısaca onayladı̆̆ımı söyleyebilirim. (Ö23)

Tablo 4. Drama atölyesinin katkıları

\begin{tabular}{|c|c|c|}
\hline Tema & Kodlar & f \\
\hline & Dersi daha iyi anlama(f:12), Kendine olan güvenin artması(f:6), & \\
Erama & $\begin{array}{c}\text { Eğlence(f:5), Kendimi daha iyi ifade etme(f:3), Öğrenme(f:1), } \\
\text { Sevdim(f:1), Mutlu olma(f:1), Daha sosyal olma(f:1), Dramaya karşı }\end{array}$ & 39 \\
atölyesinin & $\begin{array}{c}\text { bakış açısının değişmesi(f:1), Empati kurma(f:1), Olayları kurgusal bir } \\
\text { katkıları }\end{array}$ & \\
& biçimde anlama(f:1), Zevkli(f:1), Bilgi(f:1), Severek ders işleme(f:1), & \\
& Yardımcı olma(f:1) & \\
\hline
\end{tabular}

Tablo 4' de görüldüğü gibi, öğrencilere birinci tema doğrultusunda proje kapsamında yapılan drama atölyelerinin katkıları sorulmuştur. Öğrencilerin verdikleri cevaplardan hareketle en çok, "Dersi daha iyi anlama(f:12)", "Kendime olan güvenin artması(f:6)" ve "Eğlence(f:5)" kodlarının ön plana çıktığı görülmektedir. Bundan sonra sırasıyla "Kendimi daha iyi ifade etme(f:3)", “Öğrenme(f:1)", “Sevdim(f:1)”, "Mutlu olma(f:1)”, "Daha sosyal olma(f:1)”, "Dramaya karş1 
bakış açısının değişmesi(f:1)", "Empati kurma(f:1)", "Olayları kurgusal bir biçimde anlama(f:1)", “Zevkli(f:1)", "Bilgi(f:1)", "Severek ders işleme(f:1)", "Yardımcı olma(f:1)"kodları yer almaktadır.

Aşağıda öğrencilerin yaptıkları açıklamalardan örnekler verilmiştir.

Drama yöntemi ile ders yapıldı̆̆ında daha iyi anlıyorum. (Ö4)

Sizinle yaptığımız drama atölyesi çok etkili bir çalışma oldu. Çünkü hem eğlendim, hem de ögrendim. Sizinle yaptı̆̆ım dersleri çok seviyorum.(Ö8)

Tablo 5. Dramanın olumlu ve olumsuz özellikleri

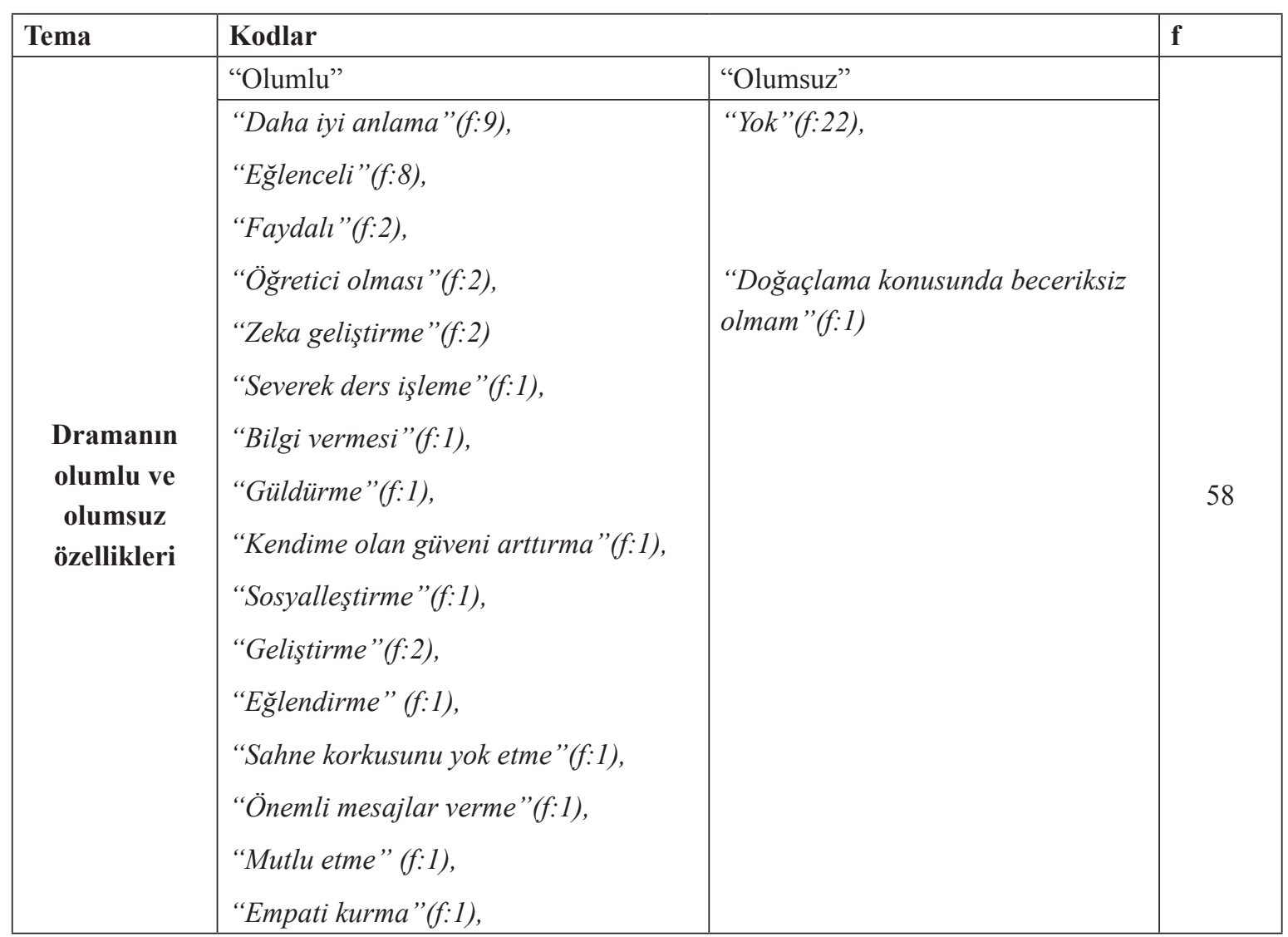

Tablo5' de görüldüğü gibi, öğrencilere birincitema doğrultusunda dramanın olumlu veolumsuz özellikleri sorulmuştur. Öğrencilerin verdikleri cevaplardan hareketle en çok, Daha iyi anlama(f:9), ve Eğlenceli(f:8)kodlarının ön plana çıktığı görülmektedir. Bundan sonra sırasıyla"Faydalı(f:2)", "Öğretici olması(f:2)", "Zeka geliştirme(f:2)", "Severek ders işleme(f:1)", "Bilgi vermesi(f:1)", "Güldürme(f:1)", "Kendime olan güveni arttırma(f:1)", "Sosyalleştirme(f:1)", "Geliştirme(f:2)", "Eğlendirme(f:1)", "Sahne korkusunu yok etme(f:1)", "Önemli mesajlar verme(f:1)”, "Mutlu etme (f:1)", "Empati kurma(f:1)"kodları yer almaktadır.

Aşağıda öğrencilerin yaptıkları açıklamalardan örnekler verilmiştir.

Drama bence başlı başına olumlu bişeydir.

Olumsuz bir yönünü sayamam ama olumlu olarak insanı geliştirirken Sosyalleştirirken bir yandan da ĕglendirmesi (Ö11) 
Insanın sahne korkusunu yok eder. Olumsuz özelliği yok, çünkü çok faydalı.(Ö22)

Tablo 6. Müzede drama uygulaması ile ilgili düşünceler

\begin{tabular}{|c|c|c|}
\hline Tema & Kodlar & $\mathbf{f}$ \\
\hline $\begin{array}{c}\text { Müzede drama } \\
\text { uygulaması }\end{array}$ & 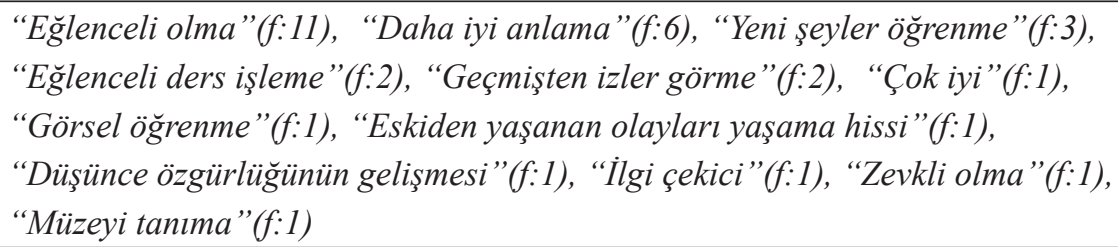 & 31 \\
\hline
\end{tabular}

Tablo 6'da görüldüğü gibi, öğrencilere birinci tema doğrultusunda İzmir Atatürk Müzesinde yapılan drama atölyesi ile ilgili düşünceleri sorulmuştur. Öğrencilerin verdikleri cevaplardan hareketle en çok, "Eğlenceli olma(f:11)" ve "Daha iyi anlama(f:6)"kodlarının ön plana çıktığ1 görülmektedir. Bundan sonra sırasıyla "Yeni şeyler öğrenme(f:3)", "Eğlenceli ders işleme(f:2)", "Geçmişten izler görme(f:2)", "Çok iyi(f:1)", "Görsel öğrenme(f:1)", "Eskiden yaşanan olayları yaşama hissi(f:1)”, “Düşünce özgürlüğünün gelişmesi(f:1)”, "İlgi çekici(f:1)”, “Zevkli olma(f:1)”, "Müzeyi tanıma(f:1)"kodları yer almaktadır.

Aşağıda öğrencilerin yaptıkları açıklamalardan örnekler verilmiştir.

Bilmediğim konuları yada bilgileri daha iyi anladım, görsel bir şekilde anladım, çok güzel buldum.(Ö5)

Hem daha çok bilgi edindim hem de eğlenerek öğrendim. Böylece aklımda kalıcı bir yer edindi. (Ö7)

\section{Sınıf öğrencilerinin ders işlenişi ile ilgili düşünce ve beklentilerine yönelik görüşlerine ilişkin bulgular}

Tema 2: 8. Sını öğrencilerinin ders işlenişi ile ilgili düşünceleri ve beklentileri

Tablo 7. Inkılâp Tarihi dersini sevme durumu

\begin{tabular}{|l|l|c|}
\hline Tema & Kodlar & f \\
\hline $\begin{array}{c}\text { İnkılap Tarihi } \\
\text { dersini sevme } \\
\text { durumu }\end{array}$ & $\begin{array}{l}\text { "Evet”(f:16), “Eğlenceli”(f:3), “Güzel”(f:2), “Bazen sıkıcı”(f:3), "Biraz } \\
\text { seviyorum”(f:2), “Hayır”(f:1), “İlgi çekici”(f:1), “Drama ile işlenince }\end{array}$ & 29 \\
\hline
\end{tabular}

Tablo 7'de görüldüğ̈̈ gibi, öğrencilere ikinci tema doğrultusunda T.C İnkılap Tarihi ve Atatürkçülük dersini sevme durumları sorulmuştur. Öğrencilerin verdikleri cevaplardan hareketle en çok, "Evet(f:16)"kodunun ön plana çıktığı görülmektedir. Bundan sonra sırasıyla "Eğlenceli(f:3)", "Güzel(f:2)", "Bazen sıkıcı(f:3)”, "Biraz seviyorum(f:2)", "Hayır(f:1)”, “İlgi çekici(f:1)”, "Drama ile işlenince seviyorum(f:1)"kodları yer almaktadır.

Tablo 8. Ders işleniş şekli

\begin{tabular}{|c|l|c|}
\hline Tema & Kodlar & f \\
\hline $\begin{array}{c}\text { Ders işleniş } \\
\text { şekli }\end{array}$ & $\begin{array}{l}\text { "Yazı yazma”(f:15), “Konu anlatımı"(f:14), “Ders kitabından okuma } \\
\text { yapma”(f:5), “Test”(f:5), “Eğlenceli”(f:2), “Zevkli”(f:1), “Soru- } \\
\text { cevap"(f:1) }\end{array}$ & 43 \\
\hline
\end{tabular}


Tablo 8'de görüldüğü gibi, öğrencilere ikinci tema doğrultusunda T.C İnkılâp Tarihi ve Atatürkçülük dersinin nasıl işlendiği sorulmuştur. Öğrencilerin verdikleri cevaplardan hareketle en çok, "Yazı yazma(f:15)" ve "Konu anlatımı(f:14)"kodlarının ön plana çıktığı görülmektedir. Bundan sonra sirasılla“Ders kitabından okuma yapma(f:5)", "Test(f:5)", "Eğlenceli(f:2)”, "Zevkli(f:1)”, "Soru-cevap(f:1)"kodları yer almaktadır.

Aşağıda öğrencilerin yaptıkları açıklamalardan örnekler verilmiştir.

Ögretmen anlatıyor önce konuları, daha sonra da biz deftere yazıyoruz.(Ö12)

Hoca ders anlatıyor, sonra onu deftere yazdirlyor, sonrasında ise test çözdürüyor ders böyle geçiyor. (Ö19)

Tablo 9. Derste farklı etkinlikler uygulanmasını isteme durumu

\begin{tabular}{|l|l|l|}
\hline Tema & Kodlar & f \\
\hline $\begin{array}{c}\text { Derste farklı } \\
\text { etkinlikler }\end{array}$ & "Evet" $(f: 23)$, & \\
uygulanmasını & "Drama" $(f: 6)$, & 23 \\
isteme durumu & "Slayt" $(f: 2)$ & \\
\hline
\end{tabular}

Tablo 9'da görüldüğü gibi, öğrencilere ikinci tema doğrultusunda T.C İnkılâp Tarihi ve Atatürkçülük derslerinde farklı etkinlikler uygulanmasını isteme durumları sorulmuştur. Öğrencilerin verdikleri cevaplardan hareketle, öğrencilerin tamamının "Evet(f:23)"kodunu belirttiği görülmektedir. Bundan sonra sırasıyla“Drama(f:6)", ve“Slayt(f:2)”kodları yer almaktadır.

Tablo 10. Derste uygulamak istedikleri etkinlikler

\begin{tabular}{|c|l|c|}
\hline Tema & Kodlar & f \\
\hline $\begin{array}{c}\text { Derste } \\
\text { uygulamak } \\
\text { istedikleri } \\
\text { etkinlikler }\end{array}$ & Drama(f:14), Ĕ̆lenceli anlatım(f:6), Slayt(f:4), Oyunla öğretim(f:3), Konu & \\
anlatma(f:2), Test çözme(f:2), Bilgisayar(:1), Görsel zekaya yönelik ders & \\
\hline
\end{tabular}

Tablo 10’ da görüldüğü gibi, öğrencilere ikinci tema doğrultusunda T.C İnkılâp Tarihi ve Atatürkçülük ders öğretmeni olsalar dersi nasıl işlemek istedikleri sorulmuştur. Öğrencilerin verdikleri cevaplardan hareketle en çok, "Drama(f:14)" kodunun ön plana çıktığı görülmektedir. Bundan sonra sirasıyla "Eğlenceli anlatım(f:6)", "Slayt(f:4)", "Oyunla öğretim(f:3)", "Konu anlatma(f:2)", "Test çözme(f:2)","Bilgisayar(:1)", "Görsel zekaya yönelik ders işleme(f:1)”, "Videolu anlatım(f:1)"kodları yer almaktadır.

Aşağıda öğrencilerin yaptıkları açıklamalardan örnekler verilmiştir.

Slayt ve drama ile dersi işlerdim. Ben öğrencilere dersi ĕglenerek öğretirdim. (Ö12)

Sanırım videolu anlatımla dersi desteklerdim. (Ö16) 


\section{Sınıf öğrencilerinin ders işlenişi ile ilgili düşünce ve beklentilerine yönelik görüşlerine ilişkin günlüklerinden elde edilen bulgular}

Tema 3: 8. Sinıf öğrencilerinin atölye sürecine dair görüşleri

Tablo 11. Atölye sürecine ilişkin hissedilenler

\begin{tabular}{|c|c|c|}
\hline Süreç & Kodlar & f \\
\hline 9 Hafta & 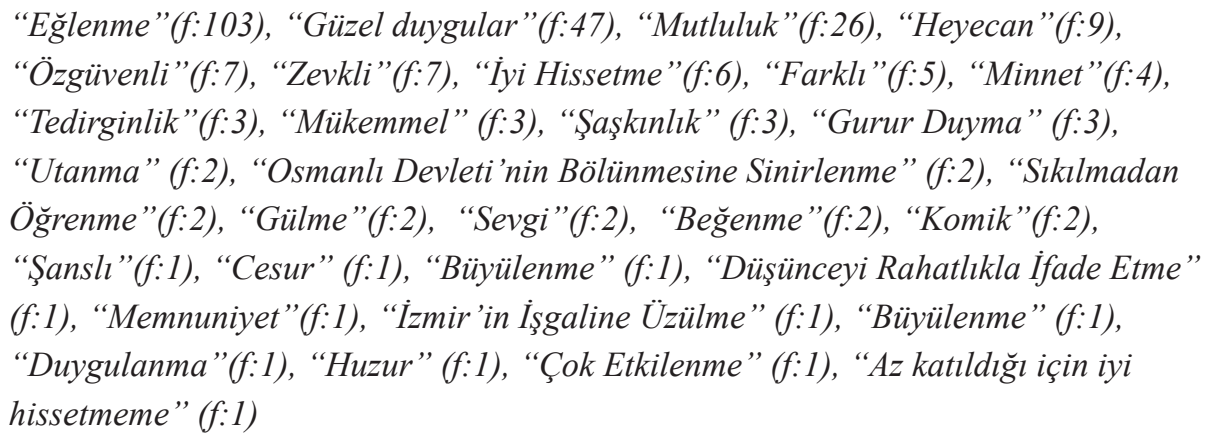 & 251 \\
\hline
\end{tabular}

Tablo 11' de görüldüğü gibi, öğrenciler üçüncü tema doğrultusunda tuttukları günlüklerde 9 hafta boyunca atölye sürecine ilişkin neler hissettikleri sorulmuştur. Öğrencilerin verdikleri cevaplardan hareketle en çok, "Eğlenme(f:103)" kodunun ön plana çıktığ görülmektedir. Bundan sonra sirasıyla “Güzel Duygular (f:47)”, "Mutluluk (f:26)", "Heyecan(f:9)” vd kodlar yer almaktadır.

Tablo 12. Atölye sürecinde ögrenilenler

\begin{tabular}{|c|c|c|}
\hline Süreç & Kodlar & f \\
\hline 9 Hafta & 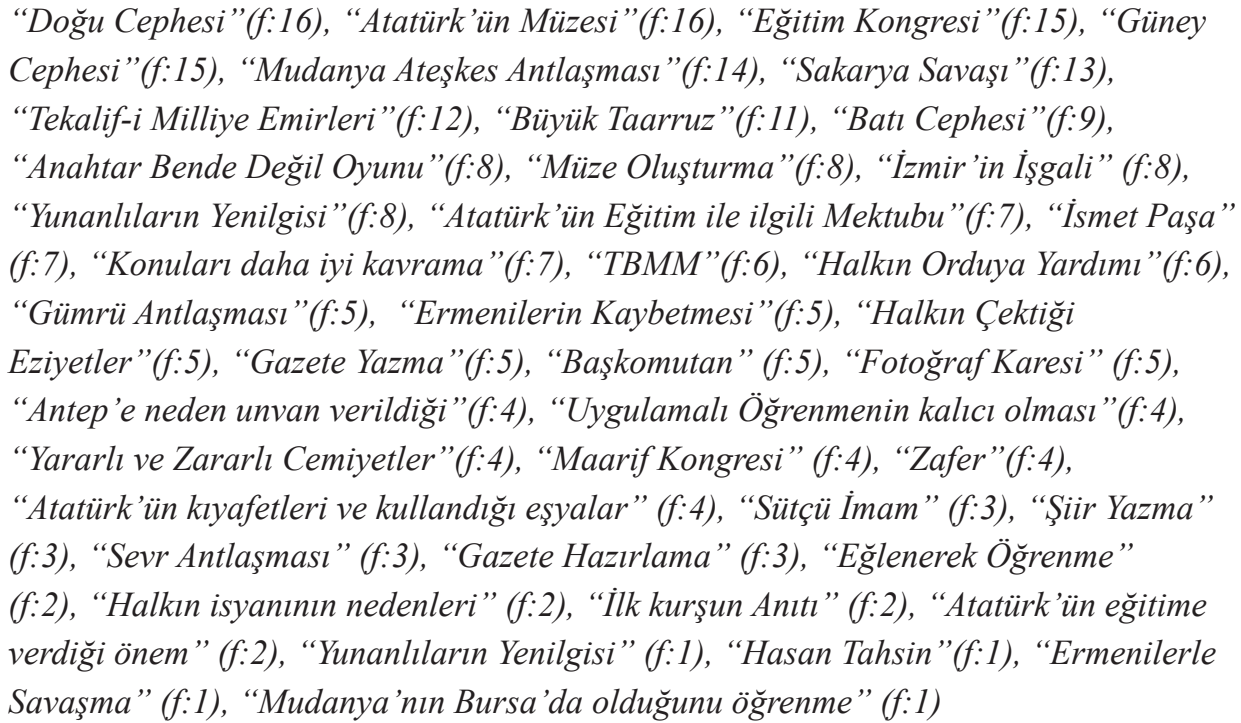 & 249 \\
\hline
\end{tabular}

Tablo 12' de görüldüğü gibi, öğrenciler üçüncü tema doğrultusunda tuttukları günlüklerde 9 hafta boyunca atölye sürecinde öğrenilenler sorulmuştur. Öğrencilerin verdikleri cevaplardan hareketle en çok, "Doğu Cephesi(f:16)" ve “Atatürk’ün Müzesi(f:16) kodlarının ön plana çıktığ1 görülmektedir. 


\section{Tartışma ve Sonuç}

Birinci tema doğrultusunda öğrencilerin yaratıcı drama yöntemine ilişkin görüşlerine yer verilmiştir. Araştırma bulgularından hareketle çalışma yapılan grubun yarıdan fazlası daha önce hiçbir drama etkinliğinde bulunmadığı, bununla birlikte öğrencilerin dramayı tanımlarken “eğlenceli”, "doğaçlama”, "oyun” gibi olumlu ifadeler kullandıkları görülmektedir. Öğrencilerin dramaya yönelik olumlu önyargılarının olması, öğrencilerin tamamının drama yöntemi ile ders işlenebileceğini düşünmesine neden olmuştur. $\mathrm{Bu}$ olumlu bakış açısı atölyelere de yansımış, öğrencilerin yapılan etkinliklere oldukça istekli bir şekilde katıldıkları gözlemlenmiştir. Öğrencilere süreç sonunda dramanın olumlu ve olumsuz özellikleri sorulmuş, öğrencilerin tamamına yakını dramanın olumsuz bir özelliği olmadığını belirtmiştir. Drama yöntemi ile işlenen derslerin kendilerine katkıları sorulduğunda ise öğrenciler en çok "dersi daha iyi anlama” kodunu kullanmışlardır. Drama derslerinin tarih derslerinde kullanılması ile öğrencilerin tarihsel olay ve olguları içselleştirdikleri ve olayları hayal ederek zihinlerinde daha anlamlı bir hale getirdikleri açıktır. Araştırma bulgularında da görüldüğü gibi T.C. İnkılâp Tarihi ve Atatürkçülük derslerinde öğrencilerin hayatlarından uzak ve soyut kavramların öğretiminde öğrencilerin yaşayarak, canlandırarak somut verilerle öğrenmesini sağlayan drama yönteminin öğrencilerin öğrenmesinde olumlu etkileri olduğu görülmektedir. Bu bulguyu destekleyen diğer çalışmalara baktığımızda; Koç (1999), Sosyal Bilgiler Öğretiminde Bir Yöntem Olarak Yaratıcı Dramanın Öğrenmeye Etkisi konulu yüksek lisans tezinde, 4. sınıf sosyal bilgiler programında yer alan Türklerin Anadolu'ya Yerleşmesi ünitesinde yürüttüğü araştırması sonucunda yaratıcı drama yönteminin uygulandığı deney grubunun toplam başarı puanları ile geleneksel yöntemin uygulandığı kontrol grubunun toplam başarı puanları arasında deney grubu lehine anlamlı bir fark bulmuştur. Günaydın (2008) İlköğretim 6. Sınıf sosyal bilgiler Öğretiminde Drama Yönteminin Erişi ve Tutum Üzerindeki Etkisi isimli yüksek lisans tezinde Sosyal Bilgiler öğretiminde, yaratıcı dramanın uygulandığ 1 deney grubunun uygulamadan önceki başarı durumları ile uygulama sonrası başarı durumları arasında anlamlı bir fark olduğu belirlendiğinden yaratıcı dramanın etkili bir öğretim yöntemi olduğu sonucuna ulaşmıştır. Daha önce yapılan bu çalışmalara bakıldığında, çalışmamızla benzer nitelikte drama yönteminin eğitimde kullanımı açısından olumlu sonuçlar alındığı görülmektedir.

Çalışma sonucunda birinci tema doğrultusunda öğrencilere, müzede yapılan drama uygulaması ile ilgili neler düşündükleri sorulmuştur. Öğrenciler en çok; "eğlenceli bulma" ve "daha iyi anlama" kodlarını kullanmışlardır. Öğrencilerin tamamı ilk kez müzede drama etkinlikleri yapmışlardır. Öğrencilerin tamamının sürece ilişkin heyecanlı oldukları ve yapılan etkinliklere istekli katıldıkları görülmüştür. Öğrenci günlüklerinde bulunan verilerinde bu durumu destekler nitelikte olduğu görülmektedir. Okul dışında yapılan etkinliklerin en önemlilerinden biri de müzelerdir. Tarih eğitimi açısından müze ve tarihi mekan gezileri öğrencilerin öğrenmelerinde etkili olmaktadır. $\mathrm{Bu}$ bağlamda müzelerde yapılan drama ve rol oynama etkinliklerinin aktif öğrenmeye en uygun öğrenme alanlarından biri olduğu düşünülmektedir. Bu bulguyu destekler nitelikte olan Yılmaz ve Şeker (2011), yaptıkları araştırmada öğrencilerin büyük bir kısmının bilgi, görsellik ve genel kültür açısından müze gezilerinin kendilerine çok yarar sağladığını, tarih, coğrafya ve genel kültür alanında kendilerini geliştirmelerine yardım ettiğini düşündükleri ve sosyal bilgiler öğretiminde müze gezilerinin düzenlenmesinin gerekli olduğuna inandıklarını tespit etmişlerdir. 
Öğrencilere ikinci tema doğrultusunda T.C. İnkılâp Tarihi ve Atatürk derslerinin işlenişine dair düşünce ve beklentileri sorulmuştur. Araştırma bulgularından hareketle öğrencilerin büyük bölümü tarih derslerini sevdiklerini belirtmişlerdir. Bununla birlikte öğrencilerin tamamı tarih derslerinde farklı etkinliklerin uygulanmasını istediklerini belirtmişlerdir. Öğrencilere dersi nasıl işledikleri sorulduğunda en çok kullanılan kodun "yazı yazma" ve "konu anlatımı" olması dikkat çeken bir sonuçtur. Ayrıca öğrencilere kendileri öğretmen olsaydı tarih derslerini nasıl işlemek istedikleri sorulmuştur. Öğrencileri en çok drama ve eğlenceli anlatım kodlarını kullanmışlardır. Yazı yazma ve sunuş yoluyla anlatım gibi klasik yöntemlerle işlenen tarih derslerinde öğrencilerin aktif olamadıkları açıktır. Bu öğrenme ortamlarında öğrencilerin kalıcı öğrenme, olaylara çok boyutlu bakma, empati kurma, yorum yapma, analiz ve sentez yapma gibi becerilerinin gelişmediği, tarihi olay ve olguların ezberlendiği görülmektedir. Bu bağlamda hedeflenen davranış değişikliklerini gerçekleştirmek için eğitim sürecinde, öğrencilerin pasif alıcı olmalarına neden olan bu gibi yöntem ve tekniklerin yanı sıra öğrencilerin aktif olabilecekleri grup çalışması, sözlü tarih, canlandırma gibi etkinliklere daha fazla yer verilmesi gerektiği düşünülmektedir.

Üçüncü tema doğrultusunda öğrencilerden sürece ilişkin hissettiklerini ve ne öğrendiklerini anlatan günlük tutmaları istenmiştir. Öğrencilerin tuttukları günlüklerdeki verilerden hareketle öğrencilerin sürece ilişkin "eğlenme", "heyecan" ve mutluluk" gibi olumlu duygu ifadeleri kullandıkları görülmüştür. Bununla birlikte öğrenciler drama atölyelerinin özgüvenleri üzerinde olumlu katkıları olduğunu belirtikleri görülmüştür. Drama yönteminin ders öğretimi yanında öğrencilerin kişilik gelişimleri üzerinde de olumlu etkileri olduğu açıktır. Öğrencilerin sosyalleşme, kendini ifade edebilme, kendini ve yeteneklerini keşfetme noktasında drama çalışmalarının katkısının önemli olduğu düşünülmektedir. Öğrenci günlüklerindeki verilerden hareketle öğrencilerin öğrenmelerinde olumlu yönde gelişmeler olduğu görülmüştür. Öğrenciler atölye sonunda atölye konularını günlüklerine yazmış ve konuyu daha iyi anladıklarını belirten ifadeler kullanmışlardır.

Sonuç olarak yapılan etkinliklerle tarih derslerinde drama yönteminin kullanılmasının öğrencilerde bilişsel ve duyuşsal alanda olumlu etkileri olduğu görülmektedir. Öğrenciler için gündelik hayatlarında yer almayan, günümüzden uzak olan tarihi olay ve olgular soyuttur. Tarihsel olayların yaşanmış olaylar olduğunun kavranması, derse yönelik olumlu tutumların gelişmesi, ders kazanımlarına ulaşmak, öğrenciyi derste aktif kılmak ve yaratıcı bireyler yetiştirmek için öğretmenler bu çağdaş öğretim teknikleriyle tanışmalı ve bu teknikleri derslerinde kullanmalıdır. 


\section{Kaynakça}

Açıkgöz, K.Ü. (1998). Etkili öğrenme ve öğretme. İzmir: Kanyılmaz Yayıncılık.

Adıgüzel, H. Ö. (2017). Yaratıcı drama. Ankara: Naturel Kitap Yayıncılık.

Altıkulaç, A. \& Akhan N. E. (2010). 8. sınıf İnkılâp Tarihi ve Atatürkçülük dersinde yaratıcı drama yöntemi ve altı şapkalı düşünme tekniğinin kullanılmasının öğrenci başarı ve tutumlarına etkisi, Ahi Evran Üniversitesi Eğitim Fakültesi Dergisi.11(3).

Altunışık, R. Coşkun, R., Bayraktaroğlu, S. ve Yıldırım, E. (2005). Sosyal bilimlerde araştırma yöntemleri: SPSS uygulamall. 4. Sakarya: Sakarya Yayıncılik.

Barth, J. Demirtaş, A. (1997). İlköğretim sosyal bilgiler ögrretimi. Ankara: YÖK Dünya Bankası Milli Eğitimi Geliştirme Projesi.

Başbuğ.S.,Aykaç.M. (2012). İlköğretim okullarında müze çalışmalarının yaratıcı drama yöntemiyle yapılandırılması. San,İnci (Ed.) Çocuk müzeleri ve yaratıcı drama çocuk müzelerinin nitelik ve işlevleri semineri. Birinci Baskı.Ankara: Naturel Yayıncilık s. 185-206

Başbuğ, Songül. (2008). Sosyal bilgiler dersinde yaratıcı dramanın yöntem olarak kullanılmasının öğrenci başarısına etkisi. Yayımlanmamış Yüksek Lisans Bitirme Projesi, Ankara Üniversitesi, Eğitim Bilimleri Enstitüsü, Ankara.

Black, L. (2003). Tarih eğitimine eleştirel yaklaşımlar. 20. yüzyılda dünya ve Türkiye tarihi. İstanbul: Tarih Vakfı Yayınları.

Carr, E.H. (1996). Tarih nedir? İstanbul: İletişim Yayınları

Demircioğlu H.İ. (2009). Tarih öğretmenlerinin tarihsel düşünme becerilerine yönelik görüşleri. Milli Eğitim Dergisi, Say1. 184, 228-239.

Demircioğlu, H.İ. (2010). Tarih öğretiminde öğrenci merkezli yaklaşımlar. Ankara: Anı Yayıncılık.

Dönmez, C. (2005). Ortaöğretimde eğitim ve öğretim elemanı yetiştirme zorluğu. Türk eğitim sisteminde Atatürkçülük ve Cumhuriyet tarihi öğretimi. Ankara: Hacettepe Üniversitesi Yayınları.

Günaydın, G. (2008). İlköğretim 6. sınff sosyal bilgiler öğretiminde drama yönteminin erişi ve tutum üzerindeki etkisi. Yayınlanmamış Yüksek Lisans Tezi, Dokuz Eylül Üniversitesi Sosyal Bilimler Enstitüsü, İzmir.

Http://www.bilgicik.com/yazi/ataturkun-egitim-hakkindaki-dusunceleri-dr-cemal-avci/

Kabapınar, Y. (2014). Sosyal bilgiler ögretimi. Ankara: Pegem Yayıncılık.

Koç, F. (1999). Yaratıcı dramanın öğrenmeye etkisi. Yayınlanmamış Yüksek Lisans Tezi, Ankara Üniversitesi Sosyal Bilimler Enstitüsü.

Maxwell A. M. (1996). Qualitative research design an interactive approach. California: Sage Publications.

MEB, (1989). Tebliğler Dergisi, Mayıs:Ankara.

Okvuran A. (2003). Drama öğretmeninin yeterlilikleri. Ankara Üniversitesi Eğitim Bilimleri Fakültesi Dergisi. Say1 36

Özakman, T. (2005). Şu çılgın Türkler. İstanbul: Bilgi Yayınevi.

Özbaran, S. (1992). Tarih ve öğretimi. İstanbul: Cem Yayınevi.

Safran, M. (1998). Tarih e ğitimi ve öğretimi (Makaleler), Ankara, 94-96.

Safran, M. (2006). Türk tarihi ögrretimi ve meseleleri. Türkler Ansiklopedisi, C:17,Ankara: Yeni Türkiye Yayınları.

Safran, M. (2009). Türkiye'de tarih öğretimi ve meseleleri. Tarih öğretim yöntemleri. Ankara: Nobel Yayınları.

Silier, O. (2003). 20. yüzyılda dünya ve Türkiye tarihi. İstanbul:Tarih Vakfı Yayınları

Stradling, R. (2003). Becerileri ve kavramları geliştirmek. 20. Yüzyılda Dünya ve Türkiye Tarihi.İstanbul:Tarih Vakfı Yay1nlar1.

Şengül, T. (2011). Tarih öğretiminde drama. Tarih nasıl öğretilir? İstanbul:Yeni İnsan Yayınevi.

Tuluk, N. (2004). Yaratıcı drama. Pivolka, 3 (15)

Üstündağ, T. (1999). Yaratıcı dramanın bir yöntem olarak ilköğretimde kullanılması. Öğrenmenin oluşumu: öğretme, model, strateji ve teknikleri. İlköğretimde etkili öğretme ve öğrenme öğretmen el kitabı. Modül 1. Süleyman Demirel Üniversitesi, Burdur Eğitim Fakültesi Yayını, 117-133.

Üstündağ, T. (2002). Yaratıcılı̆̆a yolculuk. Ankara: Pagem Yayınları

Yılmaz, K. Şeker, M. (2011). İlköğretim öğrencilerinin müze gezilerine ve müzelerin sosyal bilgiler öğretiminde kullanılmasına ilişkin görüşlerinin incelenmesi. İstanbul Aydın Üniversitesi Dergisi, C.3, S.9, 21-39

Yılmaz, M. (2000). Türk eğitim sisteminde Atatürkçülük ve Cumhuriyet tarihi öğretimi. Ankara: Hacettepe Üniversitesi Yayınlar1. 


\section{Ek 1: Örnek Ders Planı}

Ders: T.C İnkılap Tarihi ve Atatürkçülük

Sinıf: 8

Süre: $40+40$

Tema: Ya İstiklal Ya Ölüm

Konu: Doğu Cephesi

Mekan: Egekent/2 Ortaokulu 8/A sinıfi

Araç ve Gereçler: Kraft kağıdı, boya kalemleri

Yöntem Teknikler: Yaratıcı Drama (Rol oynama, Doğaçlama, Eş Zamanlı Doğaçlama)

\section{Kazanımlar:}

1) Doğu cephesinin kuruluş nedenlerini bilir.

2) Doğu cephesinin sonuçlarını söyler.

Isınma-Hazırlık:

\section{Etkinlik}

Balık Ăğ oyunu:

Öğretmen grubu çembere davet eder. Öğrencilere balık ağı oyunu oynanacağı söylenir. Oyun için ortaya gönüllü olan iki öğrenci seçilir. Gönüllü öğrenciler kol kola girer. Bu ikilinin ağ olduğu, diğer öğrencilerin ise balık olduğu belirtilir. Ağ rolündeki öğrencilerin amacı ağı koparmadan, balıkların hepsini yakamaya çalışmak ve ağa eklemektir. Balık rolündeki öğrencilerin amacı ise ağa yakalanmayan en son kişi olmaktır. Balıklar yakalanırken ağda kopmalar olursa ağın koptuğu nokta ya da noktalardaki iki öğrenci oyun dışı kalır. Öğretmenin işaretiyle oyun başlar.

\section{Etkinlik}

Öğretmen tarafindan öğrencilere 1. etkinlikte oynanan oyun üzerinden “Oyun ve Kurtuluş Savaşı arasında nasıl bir bağ kurulabilir?" "Türkiye'nin kuruluşu hakkında neler biliyorsunuz?" Soruları sorulur. Öğrenci görüşleri alındıktan sonra öğretmen Kurtuluş Savaşı'nda açılan Doğu Cephesi, Batı Cephesi ve Güney Cephesi olduğu bilgisini verir. Batı ve Güney cepheleri ile ilgili ayrıntılı değerlendirme yapılır. Doğu cephesi ile ilgili öğrencilerin yazılı görüşlerine başvurulur. Mekâna önceden asılan kraft kâğıda her öğrenci sıra ile bildiklerini tek kelime ya da tek cümle ile yazar. Öğretmen tarafından Doğu Cephesi hakkında temel bilgiler verilir. Daha sonra öğrencilerin yazdıkları okunur. Öğretmenin anlattıkları ile yazılanlar karşılaştırılır, yanlış olanların üzeri çizilir.

\section{Etkinlik}

İrlanda düellosu:

Öğrenciler çember biçimindedir. İrlanda düellosu oynayacaklarını belirtir. Öğretmenin yönergesiyle öğrenciler mekânda dağınık biçimde durur. Öğrencilere sağ işaret parmakları dışarıda duracak şekilde, sağ kollarını kaldırmaları gerektiği belirtilir. Bu öğrencilerin kılıçlarıdır. Sol ellerinin avuç içi ise dışarı bakacak biçimde bel bölgesinde sabitlenir. Sol el avuç içleri öğrencilerin kalpleridir. Amaçları avuçlarından vurulmamak, aynı zamanda sağ işaret parmaklarıyla bir başkasını 
vurmaktır. Öğretmenin yönergesiyle katılımcılar kılıçları ile kalpleri vurmaya çalışır. Vurulan katılımcı oyundan çıkar. Oyun tek kazanan kalıncaya kadar devam eder.

\section{Canlandirma}

\section{Etkinlik}

Grup Doğu cephesi ile ilgili kavramlardan oluşan örüntü yoluyla dört gruba ayrılır. Örüntüde sırasıyla “doğu”, "cephe”, "Kazım”, "Karabekir” kelimeleri kullanılır.

Her gruba kraft kâğıdı verilir. Gruplardan ;"Birinci dünya savaşı yıllarında, farklı uluslardan oluşan bir ülke kurgulamaları, kurguladıkları ülkeyi anlatan bir resim ve belirledikleri ülkenin bayrağını çizmeleri söylenir. Çizimler tamamlandıktan sonra her grup ülkesine bir ad verir. Gruplar savaş yıllarında ülkelerinin öne çıkan beş sorununu belirler. Savaş yıllarında ve çok uluslu ülkelerinin öne çıkan sorunlarının anlatıldığı belgesel program formatında $3 \mathrm{dk}$ 'lık canlandırma yapmaları söylenir.

\section{Etkinlik}

Öğretmen öğrencilere "Kurtuluş Savaşı yıllarıdır. Zor günler yaşanmaktadır. Coğrafyanızda yüzyıllardır birlikte yaşadığınız Ermeni halkının bir devlet kurmak için ayaklanacağı ve bunun da diğer işgalci güçler tarafından desteklendiği bilinmektedir. Ancak Ermeni halkının bunu yapmasında başka nedenlerde vardır.” ön bilgisini verir. Öğrenciler A ve B olarak iki gruba ayrılır. A'lar Ermenileri temsil eden rolünde, B'ler ise dönemin devlet yetkilisi rolündedir. Eş zamanlı doğaçlama yapılır.

A’nın amacı: Yıllardır bu topraklarda yaşayan Ermeni' dir. Kendilerine eşit davranılmadığını, hep aşağılandıklarını düşünmektedirler. Bunu devlet yetkilisine söyleyecektir.

B'nin amacı: Devlet yetkilisidir ve A'ları dinlemek istememektedir. Çünkü devlet halkına her zaman eşit davranır düşüncesindedir.

Eş zamanlı doğaçlama sonrası aynı ikililerin rolünün amaçları değiştirilir. İkili doğaçlama yapilir.

A’nın amacı: O bölgede çıkarları olan İngiltere ve Fransa gibi güçlü ülkelerin yetkilisidir. O bölgede bir Ermeni devleti kurulması çıkarlarına uygundur. Bu yüzden Ermenileri desteklemektedirler.

B’nin amacı: Ermeni halkıdır. Kendilerinin dinlenilmediğini düşünmektedir. Farklı bir ülkenin yetkilisiyle görüşeceklerdir.

\section{Etkinlik}

Grup A ve B olarak ikiye ayrılır. A'lar ve B'ler Gümrü anlaşmasının taraflarıdır. A'lar TBMM'yi B'ler ise Ermenistan'1 temsil etmektedir. Tüm grup doğaçlaması yoluyla Gümrü Anlaşması'nın neden ve sonuçlarının işlendiği canlandırma yapılır.

\section{Değerlendirme}

\section{Etkinlik}

Öğrenciler sayma yoluyla dört gruba ayrilır. Gruplar İngiliz Gazetesi, Ermeni Gazetesi, Milli Mücadeleye Destek Gazetesi, İstanbul Hükümeti Gazetesi olarak adlandırılır. Gruplara Gümrü Anlaşması ve Doğu Cephesi’nde yaşananlar ile ilgili gazete hazırlamaları ve sürecin manşetlerine nasıl yansıdığını hazırlamaları söylenir. Hazırlanan gazeteler üzerinden değerlendirme yapılır. 